\title{
$\angle$ Research Square \\ Marital Status and Its Correlation with Age, Race and Gender in Prognosis of Tonsil Squamous Cell Carcinomas
}

\section{yujiao Li}

fudan university shanghai cancer center

Chaosu Hu ( $\nabla$ huchaosu62@126.com )

Fudan University Shanghai Cancer Center https://orcid.org/0000-0002-0811-8180

\section{Research}

Keywords: tonsil squamous cell carcinomas, marital status, gender, prognosis

Posted Date: August 19th, 2020

DOI: https://doi.org/10.21203/rs.3.rs-61661/v1

License: (1) This work is licensed under a Creative Commons Attribution 4.0 International License. Read Full License 


\section{Abstract}

Background: To assess the impact of marital status on tonsil squamous cell carcinomas (TSCC) prognosis and to analyze whether the impact is correlated with gender, age and race.

Methods: We examined the clinicopathological variables using Chi-squared tests and we evaluated the association between survival and different variables using the methods of Kaplan-Meier. Univariate and multivariate analyses were performed to determine the effects of each variable on survival.

Results: A total of 10720 patients were analyzed. The rate of being married was higher among Asian or Caucasian, and this rate decreased with higher tumor stage. While both married male and female survivors benefit from their marital status, we found a differential in CSS based on gender, with males benefitting more than females $(p<0.05)$. Patients who were divorced/separated/single (DSS) (male HR =1.733, 95\% Cl: 1.548-1.940; female HR = 1.157, 95\% Cl: 0.887-1.507) and widowed (male HR = 2.052, 95\% Cl: 1.597-2.637; female HR =1.890, 95\% Cl: 1.374-2.599) had increased hazard of OS compared with married/partnered patients. The same results were found in OS. Subgroups analysis shows that the protective effect of marriage was consistent in all patients except for N3 groups (all, $p<0.05)$.

Conclusion: While there are survival benefits for married patients with TSCC, married/partnered males may benefit more than females. Age, race, and gender could affect the correlation between marital status and survival. However, when considering patients affected by more aggressive disease(N3 disease), the effect of marital status would be vanished.

\section{Highlights}

1. Married/partnered males may benefit more than females.

2. Age, race, and gender could affect the correlation between marital status and survival.

3. The effect of marital status would be vanished when affected by more aggressive disease(N3 disease).

\section{Introduction}

Recent studies assessing the effect of marriage on outcomes showed that marriage was associated with better survival, and the protective effect of marriage might result from that married people were associated with earlier stage and more likely to receive recommended or aggressive treatment,which was known as "spousal surveillance"

[1-6]. In addition, married patients were considered to have more emotional and financial support, which helps them to prolong their overall survival[7-9]. However, analysis of marital subgroup, which might reveal the potential mechanism generating the influence of marital status on prognosis, was not further analyzed.

Tonsil squamous cell carcinoma (TSCC) is one of the most common oropharyngeal neoplasm and the incidence rates of TSCC have significantly increased in recent decades[10-12]. Understanding the correlation between marital status and gender, race and age is important for developing tailored interventions aimed at improving socioemotional support for patients. 
Therefore, the objective of this study is to assess the clinical correlates between marital status and survival and whether the association varied by gender, race and age for TSCC using the Surveillance, Epidemiology and End Results (SEER) database.

\section{Materials And Methods Cohort population}

We obtained data from the current SEER database, which consists of 18 population-based cancer registries. This database collects and publishes cancer prevalence and survival data covering approximately $28 \%$ of the total population in the United States. SEER*Stat Version 8.3.4 (http://www. seer.cancer.gov/seerstat) from the National Cancer Institute was used to identify eligible patients in this study. We included patients diagnosed with microscopically confirmed TSCC between 1 January 2004 and 31 December 2014. We selected patients with only one primary malignancy in their lifetime. We excluded patients mainly because of lack of pathology type of tumor, unknown marital status, unknown racial information or unstaged tumors. A total of 10720 TSCC patients were included.

\section{Statistical analysis}

Descriptive statistics were used to examine the baseline characteristics of the patients. Logistic regression models evaluated the interaction and covariates on early and late stage TSCC diagnosis. The primary study outcomes were overall survival (OS) and cancer-specific survival (CSS). OS was defined as time to the date of death due to any cause or the date of last follow-up. CSS was defined as time from initial treatment to death due to cancer. KaplanMeier survival curves were compared using the log-rank test. Hazard analysis was conducted using the Cox proportional hazards model. SPSS software, version 22.0 (SPSS, Chicago, IL, USA) was used for additional data processing. $P$ value of $<0.05$ was considered statistically significant for all tests.

\section{Results}

\section{Clinical Characteristics of all Patients}

Among the 10720 patients, the median age was 58 years old (range: $17-99$ years old). More than $80 \%$ patients (8835/82.4\%) were males. Among the cohort of the patients, 6389(59.6\%), 3739(34.9\%) and 592(5.5\%) patients were married/partnered, divorced/separated/single(DSS) and widowed, respectively. According to the 6th or 7th edition of UICC/AJCC Staging System, 1687(15.8\%) and 9033(84.2\%) were stage I-II and stage III-IV, respectively. The rate of being married was higher among Asian or Caucasian, and this rate decreased with higher tumor stage. Moreover, married/partnered patients received more surgeries. The clinicopathological features stratified by marital status at diagnosis are listed in Table 1. 
Table 1

Demographic characteristics of TSCC patients who were stratified by marital status

\begin{tabular}{|c|c|c|c|c|c|c|}
\hline \multirow[t]{2}{*}{ Features } & \multirow[t]{2}{*}{$\mathrm{n}$} & \multirow[t]{2}{*}{$\%$} & \multirow{2}{*}{$\begin{array}{l}\text { Married/partnered } \\
\mathrm{n}\end{array}$} & \multirow{2}{*}{$\begin{array}{l}\text { Divorced/separated/single } \\
\text { n }\end{array}$} & \multirow{2}{*}{$\begin{array}{l}\text { Widowed } \\
\mathrm{n}\end{array}$} & \multirow[t]{2}{*}{$p$} \\
\hline & & & & & & \\
\hline Gender & & & & & & 0.000 \\
\hline Male & 8835 & 82.4 & 5489 & 3064 & 282 & \\
\hline Female & 1885 & 17.6 & 900 & 675 & 310 & \\
\hline Age & & & & & & 0.000 \\
\hline$<58$ & 5165 & 48.2 & 3127 & 1964 & 74 & \\
\hline$\geq 58$ & 5555 & 51.8 & 3262 & 1775 & 518 & \\
\hline Race & & & & & & 0.000 \\
\hline Caucasian & 9385 & 87.5 & 5794 & 3097 & 494 & \\
\hline Asian & 376 & 3.5 & 247 & 108 & 21 & \\
\hline African American & 959 & 8.9 & 348 & 534 & 77 & \\
\hline Stage & & & & & & 0.000 \\
\hline I & 683 & 6.4 & 402 & 213 & 68 & \\
\hline II & 1004 & 9.4 & 606 & 321 & 77 & \\
\hline III & 2316 & 21.6 & 1426 & 756 & 134 & \\
\hline IVA & 5392 & 50.3 & 3319 & 1846 & 227 & \\
\hline IVB & 1041 & 9.7 & 498 & 481 & 62 & \\
\hline IVC & 284 & 2.6 & 138 & 122 & 24 & \\
\hline T classification & & & & & & 0.000 \\
\hline T1 & 3123 & 29.1 & 2007 & 964 & 152 & \\
\hline T2 & 4465 & 41.7 & 2760 & 1477 & 228 & \\
\hline T3 & 1234 & 11.5 & 672 & 476 & 86 & \\
\hline $\mathrm{T} 4 \mathrm{a}$ & 1208 & 11.3 & 623 & 502 & 83 & \\
\hline$T 4 b$ & 690 & 6.4 & 327 & 320 & 43 & \\
\hline $\mathrm{N}$ classification & & & & & & 0.000 \\
\hline NO & 2327 & 21.7 & 1362 & 765 & 200 & \\
\hline N1 & 2443 & 22.8 & 1488 & 811 & 144 & \\
\hline $\mathrm{N} 2 \mathrm{a}$ & 1236 & 11.5 & 794 & 401 & 41 & \\
\hline $\mathrm{N} 2 \mathrm{~b}$ & 3302 & 30.8 & 2011 & 1150 & 141 & \\
\hline
\end{tabular}




\begin{tabular}{|c|c|c|c|c|c|c|}
\hline \multirow[t]{2}{*}{ Features } & \multirow[t]{2}{*}{$\mathbf{n}$} & \multirow[t]{2}{*}{$\%$} & \multirow{2}{*}{$\begin{array}{l}\text { Married/partnered } \\
\mathrm{n}\end{array}$} & \multirow{2}{*}{$\begin{array}{l}\text { Divorced/separated/single } \\
\text { n }\end{array}$} & \multirow{2}{*}{$\begin{array}{l}\text { Widowed } \\
\text { n }\end{array}$} & \multirow[t]{2}{*}{$\mathbf{p}$} \\
\hline & & & & & & \\
\hline N2c & 938 & 8.8 & 503 & 392 & 43 & \\
\hline N3 & 474 & 4.4 & 231 & 220 & 23 & \\
\hline Grade & & & & & & 0.000 \\
\hline 1 & 458 & 4.3 & 264 & 165 & 29 & \\
\hline 2 & 4547 & 42.4 & 2591 & 1683 & 273 & \\
\hline 3 & 5715 & 53.3 & 3534 & 1891 & 290 & \\
\hline Surgery therapy & & & & & & 0.000 \\
\hline Yes & 5891 & 55.0 & 3811 & 1820 & 260 & \\
\hline No & 4829 & 45.0 & 2578 & 1919 & 332 & \\
\hline Tumor location & & & & & & 0.000 \\
\hline Tonsillar fossa & 1555 & 14.5 & 876 & 567 & 112 & \\
\hline Tonsillar pillar & 737 & 6.9 & 408 & 273 & 56 & \\
\hline $\begin{array}{l}\text { Overlapping lesion of } \\
\text { tonsil }\end{array}$ & 121 & 1.1 & 57 & 60 & 4 & \\
\hline Tonsil, NOS & 8307 & 77.5 & 5048 & 2839 & 420 & \\
\hline
\end{tabular}

Table 1. Demographic characteristics of TSCC patients who were stratified by marital status.

\section{Survival}

The overall mean follow-up of all patients in the cohort was 34.0 months (range, 0-131 months). In the univariate analysis, age, gender, marital status, grade, $\mathrm{T}$ category, $\mathrm{N}$ category, stage and surgery therapies to the primary tumor were significantly associated with OS and CSS $(P<0.01)$. Kaplan-Meier analysis indicates that the married/partnered subgroup showed better OS and CSS than the unmarried groups and the widowed patients showed worse prognosis for both genders $(P<0.001)$. (Fig. 1).

Figure 1: Kaplan-Meier analysis of OS and CSS in males and females TSCC patients. A, OS in males TSCC patients (log rank $\mathrm{P}<0.001)$. B, OS in females TSCC patients (log rank $\mathrm{P}<0.001)$. C, CSS in males TSCC patients $(\log$ rank $\mathrm{P}<$ 0.001). D, CSS in females TSCC patients (log rank $P<0.001$ ).

As previous studies had shown, age, marital status, grade, $\mathrm{T}$ category, $\mathrm{N}$ category, and surgery therapies to the primary tumor were all independent prognostic factors in the multivariable analysis. While marriage was associated with better survival for both married male and female, subgroups analysis shows a differential in CSS based on gender, with males benefitting more than females $(p<0.01)$. Patients who were DSS (male HR $=1.733,95 \% \mathrm{Cl}$ : 1.548-1.940; female HR $=1.157,95 \% \mathrm{Cl}: 0.887-1.507$ ) and widowed (male HR $=2.052,95 \% \mathrm{Cl}: 1.597-2.637$; female $\mathrm{HR}=1.890,95 \% \mathrm{Cl}: 1.374-2.599)$ had increased hazard of CSS compared with married patients (Table 2). The same results were found in OS. 
Table 2

Multivariable logistic regression for cancer-specific survival stratified by gender.

\begin{tabular}{|c|c|c|c|c|c|c|c|c|}
\hline \multirow[t]{2}{*}{ Prognostic factor } & \multicolumn{4}{|l|}{ male } & \multicolumn{4}{|c|}{ female } \\
\hline & $\begin{array}{l}P \\
\text { value }\end{array}$ & HR & $\begin{array}{l}\text { lower } \\
95 \% \\
\mathrm{Cl}\end{array}$ & $\begin{array}{l}\text { higher } \\
95 \% \\
\mathrm{Cl}\end{array}$ & $\begin{array}{l}P \\
\text { value }\end{array}$ & HR & $\begin{array}{l}\text { lower } \\
95 \% \\
\mathrm{Cl}\end{array}$ & $\begin{array}{l}\text { higher } \\
95 \% \\
\mathrm{Cl}\end{array}$ \\
\hline Age & 0.000 & & & & 0.000 & & & \\
\hline$<58$ & & 1 (reference) & & & & 1 (reference) & & \\
\hline$\geq 58$ & & 1.671 & 1.497 & 1.865 & & 1.592 & 1.232 & 2.058 \\
\hline Marital status & 0.000 & & & & 0.000 & & & \\
\hline Married/partnered & & 1(reference) & & & & 1(reference) & & \\
\hline Divorced/separated/single & & 1.733 & 1.548 & 1.940 & & 1.157 & 0.887 & 1.507 \\
\hline Widowed & & 2.052 & 1.597 & 2.637 & & 1.890 & 1.374 & 2.599 \\
\hline Race & 0.000 & & & & 0.013 & & & \\
\hline Caucasian & & 1 (reference) & & & & 1(reference) & & \\
\hline Asian & & 1.116 & .833 & 1.496 & & 0.821 & .421 & 1.604 \\
\hline African American & & 1.596 & 1.370 & 1.860 & & 1.626 & 1.187 & 2.228 \\
\hline Grade & 0.000 & & & & 0.000 & & & \\
\hline 1 & & 1(reference) & & & & 1(reference) & & \\
\hline 2 & & 0.883 & .679 & 1.149 & & 0.837 & .521 & 1.347 \\
\hline 3 & & 0.686 & .527 & .893 & & 0.572 & .353 & .928 \\
\hline T classification & 0.000 & & & & 0.000 & & & \\
\hline $\mathrm{T} 1$ & & 1 (reference) & & & & 1(reference) & & \\
\hline $\mathrm{T} 2$ & & 1.222 & 1.029 & 1.451 & & 1.441 & 1.010 & 2.056 \\
\hline T3 & & 1.532 & 1.244 & 1.888 & & 2.772 & 1.771 & 4.338 \\
\hline $\mathrm{T} 4 \mathrm{a}$ & & 2.773 & 2.292 & 3.354 & & 3.355 & 2.262 & 4.976 \\
\hline$T 4 b$ & & 3.203 & 2.605 & 3.939 & & 4.083 & 2.627 & 6.344 \\
\hline $\mathrm{N}$ classification & 0.000 & & & & 0.174 & & & \\
\hline NO & & 1(reference) & & & & 1(reference) & & \\
\hline N1 & & 1.239 & 1.038 & 1.478 & & 1.141 & .826 & 1.575 \\
\hline $\mathrm{N} 2 \mathrm{a}$ & & 0.709 & .550 & .915 & & 0.978 & .606 & 1.579 \\
\hline $\mathrm{N} 2 \mathrm{~b}$ & & 1.090 & .923 & 1.287 & & 0.829 & .589 & 1.165 \\
\hline
\end{tabular}

Abbreviations: $\mathrm{Cl}=$ confidence interval; $\mathrm{HR}=$ hazard ratio; $\mathrm{P}$ values were calculated using an adjusted Cox proportional-hazards model; 


\begin{tabular}{|c|c|c|c|c|c|c|c|c|}
\hline \multirow[t]{2}{*}{ Prognostic factor } & \multicolumn{4}{|l|}{ male } & \multicolumn{4}{|c|}{ female } \\
\hline & $\begin{array}{l}\mathrm{P} \\
\text { value }\end{array}$ & $H R$ & $\begin{array}{l}\text { lower } \\
95 \% \\
\mathrm{Cl}\end{array}$ & $\begin{array}{l}\text { higher } \\
95 \% \\
\mathrm{Cl}\end{array}$ & $\begin{array}{l}P \\
\text { value }\end{array}$ & HR & $\begin{array}{l}\text { lower } \\
95 \% \\
\mathrm{Cl}\end{array}$ & $\begin{array}{l}\text { higher } \\
95 \% \\
\mathrm{Cl}\end{array}$ \\
\hline $\mathrm{N} 2 \mathrm{c}$ & & 1.639 & 1.351 & 1.987 & & 1.475 & .996 & 2.186 \\
\hline N3 & & 1.431 & 1.132 & 1.809 & & 3.304 & 1.967 & 5.549 \\
\hline Surgery therapy & 0.000 & 2.037 & 1.798 & 2.308 & 0.000 & 2.403 & 1.838 & 3.142 \\
\hline
\end{tabular}

Table 2. Multivariable analysis of cancer-specific survival stratified by gender

\section{Effects of marital status stratified by subgroups}

To rule out the effects of these variables and further validate the effect of marital status on OS and CSS, we conducted the subgroup analysis based on these variables (Table 3). Remarkably, the protective effect of marriage was consistent in all patients except for N3 groups (all, $\mathrm{p}<0.05$ ). 
Table 3

The effect of marital status on overall survival and cancer-specific survival based on different subgroup variables.

\section{Prognostic factor}

\section{overall survival}

P HR lower $95 \%$ higher $95 \%$

value
$\mathrm{Cl}$ cancer-specific survival

$\begin{array}{llll}P & \text { HR } & \text { lower } 95 \% & \text { higher } 95 \%\end{array}$

Age

\begin{tabular}{|c|c|c|c|c|c|c|c|c|}
\hline$<58$ & 0.000 & 1.703 & 1.572 & 1.846 & 0.000 & 1.777 & 1.608 & 1.964 \\
\hline$\geq 58$ & 0.000 & 1.316 & 1.260 & 1.373 & 0.000 & 1.394 & 1.311 & 1.483 \\
\hline \multicolumn{9}{|l|}{ Race } \\
\hline Caucasian & 0.000 & 1.453 & 1.392 & 1.516 & 0.000 & 1.525 & 1.437 & 1.619 \\
\hline Asian & 0.002 & 1.424 & 1.144 & 1.773 & 0.000 & 1.715 & 1.289 & 2.282 \\
\hline $\begin{array}{l}\text { African } \\
\text { American }\end{array}$ & 0.000 & 1.357 & 1.226 & 1.501 & 0.000 & 1.428 & 1.246 & 1.637 \\
\hline \multicolumn{9}{|l|}{ Gender } \\
\hline Male & 0.000 & 1.532 & 1.459 & 1.608 & 0.000 & 1.658 & 1.554 & 1.769 \\
\hline Female & 0.000 & 1.388 & 1.297 & 1.485 & 0.000 & 1.403 & 1.272 & 1.547 \\
\hline \multicolumn{9}{|l|}{ Grade } \\
\hline 1 & 0.000 & 1.324 & 1.131 & 1.549 & 0.000 & 1.533 & 1.227 & 1.915 \\
\hline 2 & 0.000 & 1.461 & 1.384 & 1.542 & 0.000 & 1.561 & 1.446 & 1.684 \\
\hline 3 & 0.000 & 1.480 & 1.398 & 1.567 & 0.000 & 1.555 & 1.440 & 1.680 \\
\hline
\end{tabular}

T classification

\begin{tabular}{|lllllllll} 
T1 & 0.000 & 1.445 & 1.319 & 1.584 & 0.000 & 1.385 & 1.185 & 1.619 \\
\hline T2 & 0.000 & 1.426 & 1.336 & 1.522 & 0.000 & 1.442 & 1.310 & 1.588 \\
\hline T3 & 0.000 & 1.432 & 1.294 & 1.584 & 0.000 & 1.578 & 1.378 & 1.806 \\
\hline T4a & 0.000 & 1.485 & 1.363 & 1.618 & 0.000 & 1.631 & 1.462 & 1.820 \\
\hline T4b & 0.000 & 1.355 & 1.211 & 1.517 & 0.000 & 1.338 & 1.171 & 1.529 \\
\hline N classification & & & & & & & & 1.698 \\
\hline N0 & 0.000 & 1.430 & 1.334 & 1.533 & 0.000 & 1.512 & 1.346 & 1.764 \\
\hline N1 & 0.000 & 1.459 & 1.349 & 1.577 & 0.000 & 1.591 & 1.435 & 2.077 \\
\hline N2a & 0.000 & 1.408 & 1.178 & 1.684 & 0.000 & 1.635 & 1.288 & 1.730 \\
\hline N2b & 0.000 & 1.517 & 1.406 & 1.637 & 0.000 & 1.562 & 1.410 & 1.871
\end{tabular}

Abbreviations: $\mathrm{Cl}=$ confidence interval; $\mathrm{HR}=$ hazard ratio; $\mathrm{P}$ values were calculated using an adjusted Cox proportional-hazards model; 


\begin{tabular}{|c|c|c|c|c|c|c|c|c|}
\hline \multirow{2}{*}{$\begin{array}{l}\text { Prognostic } \\
\text { factor }\end{array}$} & \multicolumn{4}{|c|}{ overall survival } & \multicolumn{4}{|c|}{ cancer-specific survival } \\
\hline & $\begin{array}{l}P \\
\text { value }\end{array}$ & $H R$ & $\begin{array}{l}\text { lower 95\% } \\
\text { Cl }\end{array}$ & $\begin{array}{l}\text { higher 95\% } \\
\mathrm{Cl}\end{array}$ & $\begin{array}{l}P \\
\text { value }\end{array}$ & HR & $\begin{array}{l}\text { lower 95\% } \\
\text { Cl }\end{array}$ & $\begin{array}{l}\text { higher } 95 \% \\
\mathrm{Cl}\end{array}$ \\
\hline N3 & 0.036 & 1.214 & 1.013 & 1.456 & 0.064 & 1.216 & .988 & 1.497 \\
\hline \multicolumn{9}{|l|}{$\begin{array}{l}\text { Surgery } \\
\text { therapy }\end{array}$} \\
\hline Yes & 0.000 & 1.378 & 1.287 & 1.474 & 0.000 & 1.394 & 1.254 & 1.550 \\
\hline No & 0.000 & 1.433 & 1.367 & 1.502 & 0.000 & 1.512 & 1.421 & 1.609 \\
\hline \multicolumn{9}{|l|}{ Stage } \\
\hline I & 0.000 & 1.415 & 1.235 & 1.621 & 0.049 & 1.345 & 1.001 & 1.808 \\
\hline II & 0.000 & 1.459 & 1.298 & 1.641 & 0.001 & 1.443 & 1.171 & 1.777 \\
\hline III & 0.000 & 1.405 & 1.288 & 1.532 & 0.000 & 1.559 & 1.379 & 1.762 \\
\hline IVA & 0.000 & 1.546 & 1.455 & 1.642 & 0.000 & 1.678 & 1.547 & 1.820 \\
\hline IVB & 0.000 & 1.357 & 1.226 & 1.503 & 0.000 & 1.367 & 1.211 & 1.543 \\
\hline IVC & 0.001 & 1.306 & 1.121 & 1.522 & 0.002 & 1.336 & 1.109 & 1.610 \\
\hline
\end{tabular}

Table 3. The effect of marital status on overall survival and cancer-specific survival based on different subgroup variables

\section{Discussion}

We confirmed what previous studies had shown that marital status impacted on treatment outcome of TSCC patients in this study. Compared to other peers, the worse prognosis of widowed patients might be resulted from negative emotions and worse economic situation due to their unfavorable marital status. We further found that married/partnered males may benefit more than females. We further found that married/partnered males may benefit more than females, which relates to spousal influence on adoption of healthy behaviors, as well as support to quit harmful risk factors associated adverse outcomes[13]. Women tend to have a greater influence on their spouse's health than men because women exert more effort to control their partners' health habits $[13,14]$. Takagi et al. found that there was a spillover effect of the wife's non-smoking only among men. However, husband's non-smoking was not associated with female target's cessation[15]. Generally speaking, the support received by male patients to adopt healthier lifestyles and have a positive outlook may explain their greater survival benefit from being married, which could partly explain the observed sex-based differences.. The differential protective effect of marriage based on gender among TSCC patients is a novel finding, which is important for care planning and needs further exploration of the underlying specific mechanism behind this observation.

We then explored the effect of marital status on prognosis by different subgroups, such as age, race, stage, grade, and the surgery situation of patients. Difference of protective effect of marriage was found among variable subgroups except for N3 patients. Not only cancer, marriage also played a positive role in overall health. Cornelis et al. reported not being married, especially widowhood was associated with an increased risk of type 2 diabetes 
through unfavorable changes in lifestyle[16]. Another study of African Americans with heart failure proved that being unmarried and not living with family independently predict higher mortality and more readmissions[17]. What's more, Woojin et al. found that marriage and marital satisfaction was of great importance in determining self-rated health in East Asian countries[18]. These studies were compatible with our results that the greater impact of marital status on OS than CSS among variable subgroups.

As far as we know, this is the first SEER analysis assessing impact of age, race and gender on the association between marital status and outcomes in TSCC. Several limitations should be noted in this study. First, the SEER database does not include change of marital status after cancer diagnosis. Second, the lack of data on additional predictors of OS such as human papillomavirus (HPV) infection, p16 status, performance status, comorbidities, tobacco smoking, alcohol consumption, betel nut and mieng (a fermented ea-leaf) chewing, prevented us to adjust our analyses for these important factors. Finally, also due to the data limitations of the SEER database, positive surgical margins at final pathology were not able to be analyzed between marital status and CSS in this study.

\section{Conclusion}

Our results showed that while there are survival benefits for married/partnered patients with TSCC, married females may benefit more than males. Age, race, and gender could affect the correlation between marital status and survival. However, when considering patients affected by more aggressive disease(N3 disease), the effect of marital status would be vanished.

Declarations

Ethical Approval and Informed Consent

All procedures performed in studies involving human participants were in accordance with the ethical standards of Fudan University Shanghai Cancer Center Ethics committee and with the 1964 Helsinki declaration and its later amendments or comparable ethical standards. The experimental protocols were also approved by Fudan University Shanghai Cancer Center Ethics committee. Written informed consent was obtained from all individual participants included in the study.

\section{Declarations}

\section{Ethical Approval and Informed Consent}

All procedures performed in studies involving human participants were in accordance with the ethical standards of Fudan University Shanghai Cancer Center Ethics committee and with the 1964 Helsinki declaration and its later amendments or comparable ethical standards. The experimental protocols were also approved by Fudan University Shanghai Cancer Center Ethics committee. Written informed consent was obtained from all individual participants included in the study.

\section{Consent for publication}

Not applicable

\section{Availability of data and materials}

The datasets used and/or analysed during the current study are available from the corresponding author on reasonable request. 


\section{Competing interests}

The authors declare that they have no conflict of interest.

\section{Funding}

No

\section{Author Contributions}

Yujiao Li and Chaosu Hu have made substantial contributions to all of the following: (1) the conception and design of the study, or acquisition of data, or analysis and interpretation of data, (2) drafting the article or revising it critically for important intellectual content, (3) final approval of the version to be submitted.

\section{Acknowledgements}

We acknowledge the support of the Department of Radiation Oncology, Fudan University Shanghai Cancer Center. The views expressed in this publication are those of the authors.

\section{References}

1. Osazuwa-Peters N, Adjei BE, Chen BY, Tobo BB, Varvares MA. Association Between Head and Neck Squamous Cell Carcinoma Survival, Smoking at Diagnosis, and Marital Status. JAMA Otolaryngol Head Neck Surg. 2018;144:43-50.

2. Schaefer EW, Wilson MZ, Goldenberg D, Mackley H, Koch W, Hollenbeak CS. Effect of marriage on outcomes for elderly patients with head and neck cancer. Head Neck. 2015;37:735-42.

3. Inverso G, Mahal BA, Aizer AA, Donoff RB, Chau NG, Haddad RI. 2015.Marital status and head and neck cancer outcomes. Cancer. 121: 1273-8.

4. Aizer AA, Chen MH, McCarthy EP, Mendu ML, Koo S, Wilhite TJ, et al. 2013.Marital status and survival in patients with cancer. J Clin Oncol. 31: 3869-76.

5. Goodwin JS, Hunt WC, Key CR, Samet JM. The effect of marital status on stage, treatment, and survival of cancer patients. JAMA. 1987;258:3125-30.

6. Howren MB, Christensen AJ, Hynds KL, Van Liew JR, Funk GF. Influence of pretreatment social support on healthrelated quality of life in head and neck cancer survivors: results from a prospective study. Head Neck. 2013;35:779-87.

7. Osazuwa Peters N, Christopher KM, Cass LM, Massa ST, Hussaini AS, Behera A, et al. 2019. What's Love Got to do with it? Marital status and survival of head and neck cancer. European Journal of Cancer Care. 28.

8. Liao $P$, Lee $C$. The influence of marital status on survival for patients aged 65 years and younger with oral cavity cancer. Auris Nasus Larynx. 2018;45:1227-32.

9. Xu C, Chen YP, Liu X, Tang LL, Chen L, Mao YP, et al. 2017.Socioeconomic factors and survival in patients with non-metastatic head and neck squamous cell carcinoma. Cancer Science. 108: 1253.

10. -1262 .

\section{Figures}


A

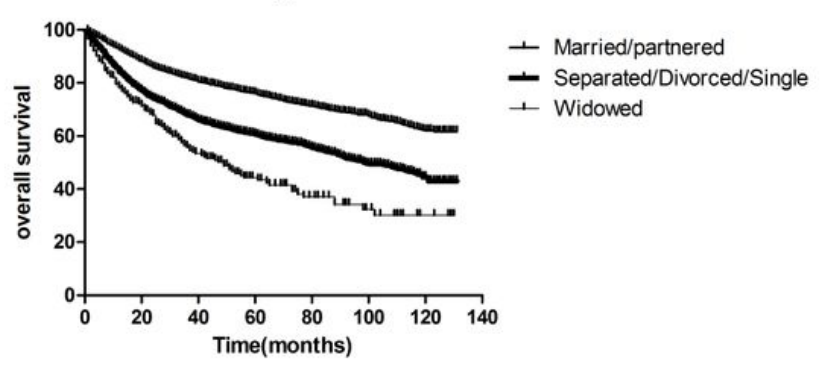

B

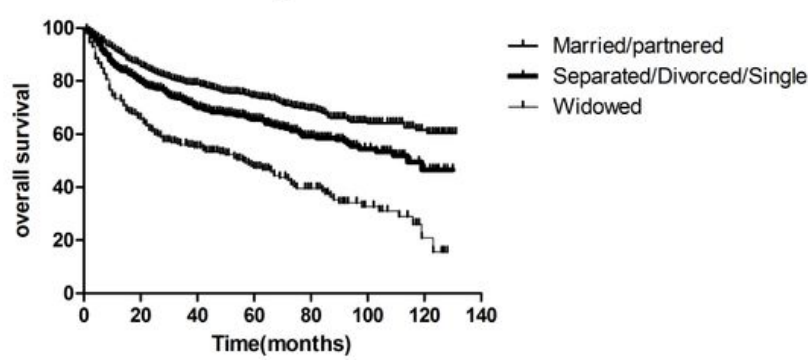

C

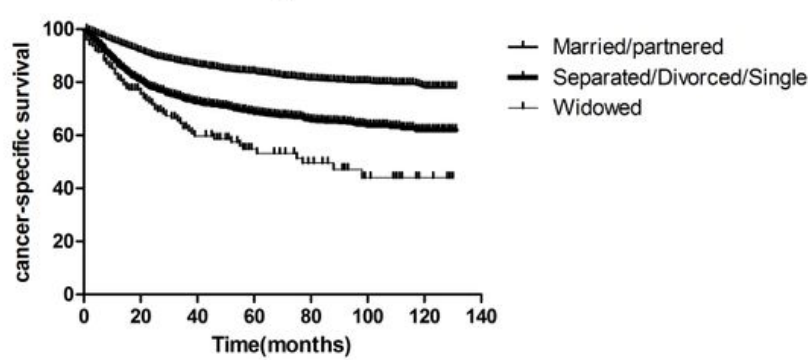

D

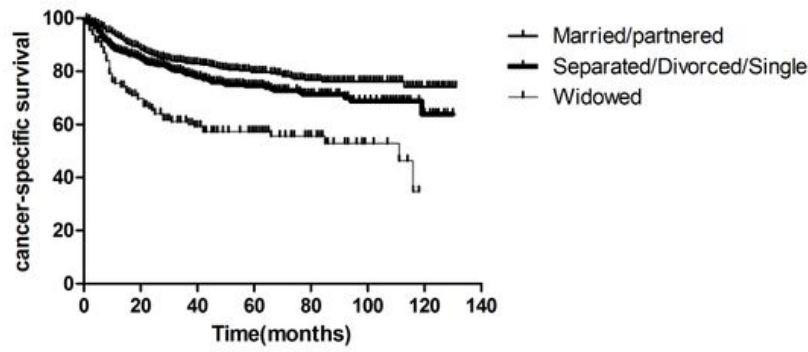

Figure 1

Kaplan-Meier analysis of OS and CSS in males and females TSCC patients. A, OS in males TSCC patients (log rank $P$ $<0.001)$. B, OS in females TSCC patients (log rank $P<0.001)$. C, CSS in males TSCC patients $(\log \operatorname{rank} P<0.001)$. D, CSS in females TSCC patients (log rank $P<0.001$ ).

\section{Supplementary Files}

This is a list of supplementary files associated with this preprint. Click to download.

- renamed0584e.doc 